\title{
Multi-Pumping Mechanised Determination of Selenium in Natural Waters by Light Emitting Diode (LED) Spectrometry
}

\author{
Ridvan N. Fernandes, ${ }^{a}$ Boaventura F. Reis, ${ }^{*, b}$ Angel Morales-Rubio ${ }^{c}$ and Miguel de la Guardia ${ }^{c}$
}

${ }^{a}$ Departamento de Química, Universidade Federal do Maranhão, Av. Portugueses, s/n, 65085-580 São Luís-MA, Brazil

${ }^{b}$ Centro de Energia Nuclear na Agricultura, Universidade de São Paulo, CP 96, 13400-970 Piracicaba-SP, Brazil

${ }^{c}$ Department of Analytical Chemistry, University of Valencia, 50 Dr. Moliner Street, 46100 Burjassot Valencia, Spain

\begin{abstract}
Um procedimento para determinação de selênio em águas, completamente mecanizado, foi desenvolvido empregando um fotômetro baseado em LED e mini-bombas solenóide como dispositivos de propulsão. O método proposto é baseado na reação de selênio com iodeto de potássio em meio ácido para liberar iodo, o qual oxida a variamina azul formando um composto violeta que absorve em $530 \mathrm{~nm}$. O sistema foi mecanizado empregando o processo de multicomutação em fluxo e uma estratégia de parada de fluxo na etapa final para desenvolvimento da reação. A curva analítica foi linear entre as concentrações de 0,010 a $0,500 \mathrm{mg} \mathrm{L}^{-1}$, segundo a equação $\Delta \mathrm{A}=0,501( \pm 0,004) \mathrm{C}(\mathrm{R}=0,999)$. O limite de detecção $(3 \sigma / \mathrm{S})$ obtido com o método proposto foi de $0,004 \mathrm{mg} \mathrm{L}^{-1}$. Desvios padrão relativo de 1,6 e $1,8 \%(\mathrm{n}=4)$ foram obtidos para soluções de Se com concentrações de 0,050 e $0,200 \mathrm{mg} \mathrm{L}^{-1}$, respectivamente. A freqüência de amostragem foi de 23 determinações por hora, e a exatidão foi de $95 \%$ de probabilidade.
\end{abstract}

It has been developed a fully mechanised procedure for the determination of selenium in waters employing a LED based spectrometer and solenoid multi-pumps as solution propelling devices. The proposed method is based on the reaction of selenium with potassium iodide in an acidic medium to liberate iodine, which oxidizes Variamine Blue to form a violet-colour species which absorb at $530 \mathrm{~nm}$. The system was mechanised using the multicommutation process and a stopped flow strategy in the final step reaction. The analytical curve was linear between 0.010 and $0.500 \mathrm{mg} \mathrm{L}^{-1}$, with an equation $\Delta \mathrm{A}=0.501( \pm 0.004) \mathrm{C}$ and $\mathrm{r}=0.999$. The limit of detection $(3 \sigma / \mathrm{S})$ obtained for the proposed method was $0.004 \mathrm{mg} \mathrm{L}^{-1}$. The relative standard deviation for Se solutions of 0.050 and $0.200 \mathrm{mg} \mathrm{L}^{-1}(\mathrm{n}=4)$ were 1.6 and $1.8 \%$ respectively, the sampling throughput was 23 determinations per hour, and accuracy was $95 \%$ probability level.

Keywords: selenium, water, multi-pumping, mechanised flow system, LED-photometry, multicommuted flow system

\section{Introduction}

Selenium is reported as a toxic element as well as an essential trace element for animals and humans. ${ }^{1,2}$ In terms of sources of selenium in the environment it can be noticed volcanic eruption, insecticides, fertilizers, smelting ceramic, metallurgical operation, glass rubber accelerators, paints, dyes and electronic goods, ${ }^{3}$ additionally there are some industrial and agricultural processes which can cause the presence of Se in natural waters, ${ }^{4}$ According to the sanitary and hygiene standards, $0.05 \mathrm{mg} \mathrm{L}^{-1}$ is the maximum permissible concentration of Se in water, ${ }^{5}$ and $0.1-0.2 \mathrm{mg} \mathrm{dm}^{-3}$

*e-mail: reis@cena.usp.br the Threshold Limit Value (TLV) for selenium compounds in air. ${ }^{6}$

Spectrophotometric methods reported in the literature for the determination of Se in water are based on the batch reaction of Se with potassium iodide in an acidic medium to liberate iodine, which oxidizes leuco malachite green, ${ }^{3}$ or Variamine Blue ${ }^{7}$ to produce a coloured product; oxidation of $p$-nitroaniline by selenium (IV) followed by reaction with $\mathrm{N}$-(1-naphthalene-1-yl)ethane-1,2-diamine dihydrochloride (NEDA) ${ }^{8}$ or previous gas extraction of Se followed by reaction with and 2-(p-nitrophenyl)-3,5diphenyltetrazolium chloride. ${ }^{9}$

Kinetic spectrophotometric methods have been also reported based on the reduction of trisodium 4,5-dihidroxi-3[( $p$-sulfophenyl)]-2,7-naphtalenedisulfonic acid by sulphide in 
micellar media ${ }^{10}$ or on acceleration of the oxidation of methyl orange with bromate in acid media after preconcentration of elemental selenium on activated carbon. ${ }^{11}$

A Flow Injection Analysis (FIA) procedure based on the oxidation of 3-methyl-2-benzothiazolinone hydrazone hydrochloride (MBTH) by selenium (IV) followed by reaction with 4.5-dihydroxy naphthalene-2,7-disulphonic acid in basic medium is the single precedent on mechanized procedures for Se determination in waters. ${ }^{12}$

In classical FIA the continuous solution pumping is made by using peristaltic pumps to propel samples and reagents. Nowadays, reagents solutions can be saved and waste reduced by employing flow manifolds based on sequential injection analysis (SIA) ${ }^{13}$ or multicommuted flow injection analyses (MCFIA) ${ }^{14}$ and multi-pumping approach. ${ }^{15}$ In the MCFIA approach, a set of solenoid valves are assembled to work as independent commutation devices requiring an external device to propel solutions. In the multi-pumping approach the flow systems comprised a set of solenoid micropumps, controlled by computer to deliver samples of solution of constant volume. ${ }^{15}$ In these systems, different flow rates should be easily achieved by varying the on/off switching pattern of the micro-pumps using a similar electronic hardware to that usually employed in multicommutation. This characteristic facilitates the construction of set-ups with small dimensions suitable for in situ use.

Micro-pumps flow systems have been used for determination of anionic surfactants in water ${ }^{16}$ and associated with pinch solenoid valves for the determination of paracetamol in pharmaceuticals. ${ }^{17}$

In this work a micro-pumping flow system was developed using a Light Emitting Diode LED based photometer and a home-made flow cell with an optical path-length of $100 \mathrm{~mm}$ for the determination of selenium in water. The method is based on the reaction of selenium with potassium iodide to liberate iodine, and the oxidation of Variamine Blue to form a violet-coloured species. Despite, the aim of the present work has been the improvement of the sensitivity, reagent consumption and throughput of photometric determination by using a low cost instrumental set-up, as compared with classical batch and FIA procedures. Finally and having in consideration the efforts in the last years to develop sustainable procedures, the proposed procedure can then be considered as a clean alternative for selenium determination in waters. ${ }^{18,19}$

\section{Experimental}

\section{Reagents and samples}

All solutions were prepared with analytical-grade chemicals and with deionised water $(18.2 \mathrm{M} \Omega \mathrm{cm})$ obtained from a Milli-Q system from Millipore (Molsheln, France).

A $1000 \mathrm{mg} \mathrm{L}^{-1}$ selenium standard was prepared for selenium dioxide Scharlau Chemie (Barcelona, Spain) in nitric acid $0.5 \mathrm{~mol} \mathrm{~L}^{-1}$. A $0.05 \%$ (m/v) 4-amino-4'-methoxydiphenylamine hydrochloride solution of the solid product from Sigma (Steinheim, Germany) was prepared dissolving $50 \mathrm{mg}$ in $25 \mathrm{~mL}$ of $99.8 \%$ (v/v) methanol from Scharlau Chemie, and making the volume to $100 \mathrm{~mL}$ with deionised water. This solution was prepared daily. $2.5 \mathrm{~mol} \mathrm{~L}^{-1}$ hydrochloric acid and $1 \mathrm{~mol} \mathrm{~L}^{-1}$ sodium acetate solutions were prepared by dilution of the appropriate amount of Scharlau Chemie reagents in deionised water. A $2 \%(\mathrm{~m} / \mathrm{v})$ potassium iodide solution in deionised water was prepared with KI Merck (Darmstadt, Germany).

For Hydride Generation Atomic Fluorescence Spectrometry (HG-AFS), a $4 \mathrm{~mol} \mathrm{~L}^{-1}$ hydrochloric acid, a $12 \%(\mathrm{~m} / \mathrm{v})$ sodium borohydride solution from Fluka (Buchs, Switzerland) and $0.1 \mathrm{~mol} \mathrm{~L}^{-1}$ sodium hydroxide solution Scharlau Chemie were prepared in deionised water.

Potential interferents, such as $\mathrm{Cl}^{-}, \mathrm{CO}_{3}^{2-}, \mathrm{NO}_{3}^{-}, \mathrm{SO}_{4}^{2-}$, $\mathrm{PO}_{4}^{3-}, \mathrm{Ca}^{2+}, \mathrm{Zn}^{2+}, \mathrm{Al}^{3+}, \mathrm{Ni}^{2+}, \mathrm{Pb}^{2+}, \mathrm{Fe}^{2+}, \mathrm{Fe}^{3+}$ and $\mathrm{Cu}^{2+}$ were evaluated for solutions containing $0.3 \mathrm{mg} \mathrm{L}^{-1} \mathrm{Se}$ plus the investigated substance at different levels.

Natural water samples were filtered through $0.45 \mu \mathrm{m}$ cellulose membrane filters and stored inside polyethylene bottles before their analysis. ${ }^{20}$

\section{Apparatus}

The flow system showed in Figure 1 comprised seven solenoid micro-pumps, from Bio-Chem Valve, 090SP (Boonton, USA); a microcomputer equipped with an electronic interface card Advantech, PCL-711S (San Jose, CA, USA); a homemade electronic interface to drive the micro-pumps similar to that described elsewhere, ${ }^{21}$ a homemade LED-based photometer, ${ }^{22}$ equipped with a flow cell with $100 \mathrm{~mm}$ optical pathlength and $2.0 \mathrm{~mm}$ inner diameter and a LED with an emission wavelength of $530 \mathrm{~nm}$; reaction coils and flow lines made of PTFE tubing ( $0.8 \mathrm{~mm}$ i.d. $)$ and home-made confluence connectors.

Six micro-pumps (P2 to $\mathrm{P} 7$ ) deliver $8 \mu \mathrm{L}$ solutions per pulse. Therefore, the volume of sample and reagent solutions inserted into the analytical path can be controlled by varying the number of the on/off switching cycles. Additionally, to clean the flow system, a $50 \mu \mathrm{L}$ pulse $^{-1}$ micro-pump (P1) was employed. The switching frequency was settled at $5 \mathrm{~Hz}$. The flow system control and data acquisition were performed by the microcomputer running software written in Quick BASIC 4.5. 


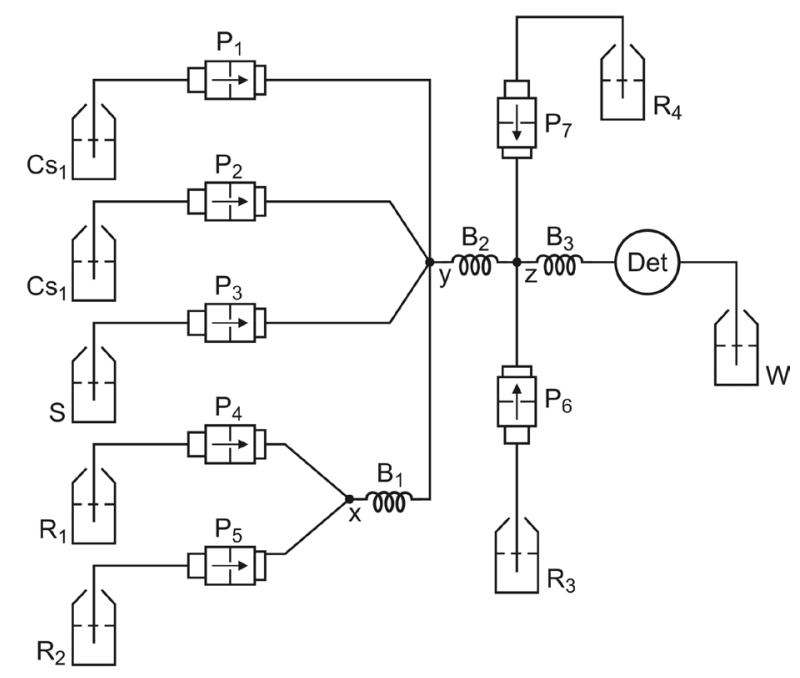

Figure 1. Diagram of the flow system. S, sample or standard solution; $\mathrm{Cs}_{1}$ and $\mathrm{Cs}_{2}$ carrier fluid, $\mathrm{H}_{2} \mathrm{O} ; \mathrm{R}_{1}, 2.5 \mathrm{~mol} \mathrm{~L}^{-1}$ hydrochloric acid solution; $\mathrm{R}_{2}$, $2 \%(\mathrm{~m} / \mathrm{v})$ potassium iodide solution; $\mathrm{R}_{3}, 1 \mathrm{~mol} \mathrm{~L}^{-1}$ sodium acetate solution; $\mathrm{R}_{4}, 0.05 \%(\mathrm{~m} / \mathrm{v})$ 4-amino-4'-methoxy-diphenylamine hydrochloride solution; $\mathrm{P}_{1}$, solenoid micro-pump, $50 \mu \mathrm{L}$ pulse $\mathrm{e}^{-1} ; \mathrm{P}_{2}, \mathrm{P}_{3}, \mathrm{P}_{4}, \mathrm{P}_{5}, \mathrm{P}_{6}$ and $\mathrm{P}_{7}$ solenoid pumps, $8 \mu \mathrm{L}$ pulse ${ }^{-1} ; \mathrm{B}_{1}, \mathrm{~B}_{2}$ and $\mathrm{B}_{3}$ reaction coils, 120,190 and $270 \mathrm{~cm}$ length respectively, $0.8 \mathrm{~mm}$ i.d. PTFE tubing; $\mathrm{x}, \mathrm{y}$ and $\mathrm{z}$ connection devices. Det, LED-photometer, $\lambda=530 \mathrm{~nm}$; W, waste.

\section{Recommended procedure}

The flow set up shown in Figure1 was designed to be operated following in the time switching micro-pump diagram indicated in Table 1.

After a prior step for filling the mixture coil B1 with hydrochloric acid (R1) and potassium iodide (R2) solutions, which was done by the sequential switching on/off of micro-pumps P4 and P5, the analytical cycle starts as indicated in Table 1.

For the operating conditions shown in Table 1, 20 sampling cycles were programmed to introduce samples and reagents solutions into the analytical path. The micro-pump P6 was switched on/off in all pulses, establishing the baseline, whereas micro-pumps P3, P4 and P5 were switched on/off sequentially. Thus, for each measurement, a total of $0.64 \mathrm{~mL}$ sample or standard were employed (corresponding to 20 cycles of 4 pulse of micro-pump P3) and, at the same time, a total of $0.16 \mathrm{~mL}$ of $2.5 \mathrm{~mol} \mathrm{~L}^{-1}$ hydrochloric acid solution and $0.16 \mathrm{~mL}$ potassium iodide solution (corresponding to 20 cycles of 1 pulse of micro-pumps P4 and P5, respectively).

Samples or standards were mixed together with $\mathrm{HCl}$ and $\mathrm{KI}$ solutions and accommodated into $\mathrm{B} 2$ reactor $(190 \mathrm{~cm})$ and the flow stopped for $45 \mathrm{~s}$ in order to obtain a satisfactory development of the reaction between potassium iodide and $\mathrm{Se}(\mathrm{IV})$.

After reaction development, the micro-pumps P2, P6 and P7 were activated sequentially to do the introduction of R3 and R4. Thirty cycles were used with 4, 2 and 1 pulses of P2, P6 and P7 respectively, in each cycle. Considering that micro-pump P6 introduces $1.0 \mathrm{~mol} \mathrm{~L}^{-1}$ sodium acetate solution and that P7 introduces $0.05 \%$ 4-amino4'-methoxy-diphenylamine hydrochloride (VB) solution, the volumes employed of each reagent ware, respectively, 0.48 and $0.24 \mathrm{~mL}$. In this step the reaction between VB and $\mathrm{I}_{2}$ was made into the $\mathrm{B} 3$ reactor $(270 \mathrm{~cm})$. After the end of fixed cycles, micro-pump P1 $(50 \mu \mathrm{L})$ was activated for pushing the coloured product zone towards the detector and to clean the system after each measurement.

The absorbance data obtained for samples were interpolated in a external calibration line achieved by introduction of different standards of Se(IV) under the same conditions as those used for samples.

\section{Results and Discussion}

\section{Effect of manifold operating conditions}

Preliminary experiments were made to establish the B1 mixture coil length. This step was very important to obtain

Table 1. Operational conditions of the flow system

\begin{tabular}{|c|c|c|c|c|c|c|c|c|c|c|}
\hline Step & Event & $\mathrm{P}_{1}$ & $\mathrm{P}_{2}$ & $\mathrm{P}_{3}$ & $\mathrm{P}_{4}$ & $\mathrm{P}_{5}$ & $\mathrm{P}_{6}$ & $\mathrm{P}_{7}$ & Pulses & cycles \\
\hline \multirow{3}{*}{1} & Introduction of S & 0 & 0 & on/off & 0 & 0 & on/off & 0 & 4 & \multirow{3}{*}{20} \\
\hline & Introduction of $\mathrm{R}_{1}$ & 0 & 0 & 0 & on/off & 0 & on/off & 0 & 1 & \\
\hline & Introduction of $\mathrm{R}_{2}$ & 0 & 0 & 0 & 0 & on/off & on/off & 0 & 1 & \\
\hline 2 & Stopped flow (45 s) & 0 & 0 & 0 & 0 & 0 & 0 & 0 & - & \\
\hline \multirow{3}{*}{3} & Introduction mixture $\mathrm{B}_{2}$ & 0 & on/off & 0 & 0 & 0 & 0 & 0 & 4 & \multirow{3}{*}{30} \\
\hline & Introduction $\mathrm{R}_{3}$ & 0 & 0 & 0 & 0 & 0 & on/off & 0 & 2 & \\
\hline & Introduction $\mathrm{R}_{4}$ & 0 & 0 & 0 & 0 & 0 & 0 & on/off & 1 & \\
\hline 4 & Transport to detection cell and cleaning & on/off & 0 & 0 & 0 & 0 & 0 & 0 & 300 & \\
\hline
\end{tabular}

Step 1 and 3 inserting of sample and reagent solutions; Step 2, stopped flow of $45 \mathrm{~s}$; Step 4, uses the micro-pump $\mathrm{P}_{1}$ to transport the reactive mixture and to clean the system after measurement; on/off: input/output solutions into/from micropump. $\mathrm{P}_{1}: 50 \mu \mathrm{L}$ volume micropump; $\mathrm{P}_{2}-\mathrm{P}_{7}: 8 \mu \mathrm{L}$ volume micropump. 
a good mixture between hydrochloric acid and potassium iodide previously to the reaction with $\mathrm{Se}(\mathrm{IV})$, specially taking into consideration that this mixture liberates iodine in presence of light, thus it has an effect on the blank signal. Figure 2, shows the effect of B1 length from 60 to $200 \mathrm{~cm}$ on the find absorption of the reaction product between iodine and VB generated after reaction of KI with $\mathrm{Se}(\mathrm{IV})$. A coil length of $120 \mathrm{~cm}$ was chosen, corresponding to an inner volume of $600 \mu \mathrm{L}$ to obtain the maximum sensitivity. The aforementioned volume was introduced through a sequence of 45 cycles of 1 pulse of micro-pump P4 and 1 pulse of $\mathrm{P} 5$.

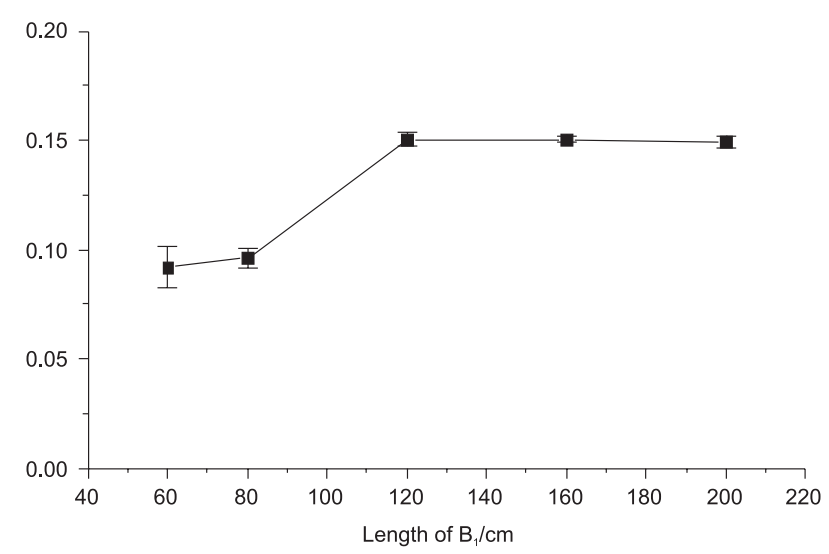

Figure 2. Effect of the mixture coil B1 length on absorbance signal. In these experiments the Se concentration was fixed at $1 \mathrm{mg} \mathrm{L}^{-1}$ being VB concentration $0.05 \%, \mathrm{KI}$ concentration of $2 \%, \mathrm{HCl}$ concentration $2 \mathrm{~mol} \mathrm{~L}^{-1}$ and sodium acetate $1 \mathrm{~mol} \mathrm{~L}^{-1} ;(\mathrm{n}=4)$.

Figure 3 shows the effect of the reaction time between $\mathrm{KI}$ in $\mathrm{HCl}$ and $\mathrm{Se}(\mathrm{IV})$. In this study $1 \mathrm{mg} \mathrm{L}^{-1} \mathrm{Se}(\mathrm{IV})$ was mixed with $\mathrm{KI}$ and $\mathrm{HCl}$ using 10 cycles including 4 pulses of $\mathrm{P} 3,1$ pulse of $\mathrm{P} 4$ and 1 pulse of $\mathrm{P} 5$. As can see, after a stopped flow time of $30 \mathrm{~s}$ it can be obtained a sensitivity enhancement of $100 \%$. Additional reaction times increase the analytical signal, but $45 \mathrm{~s}$ seems enough to obtain a good compromise between sensitivity and measurement speed.

The oxidation of iodide by selenium occurs at coil B2 and the size of this coil must be adapted to locate the mixture of $\mathrm{KI}$ and $\mathrm{HCl}$ with the sample or Se standards. $640 \mu \mathrm{L}$ sample solution $160 \mu \mathrm{L} \mathrm{HCl}$ and $160 \mu \mathrm{L}$ KI were selected and thus a reaction coil of $190 \mathrm{~cm}$ was chosen. So, the length of reaction coil $\mathrm{B} 3$ in which $\mathrm{I}_{2}$ and $\mathrm{VB}$ were located was fixed at $270 \mathrm{~cm}$ being filled on using 30 cycles of 4 pulses of P2, 2 pulses of P6 and 1 pulse of P7.

\section{Effect of reagent concentration}

The concentration of hydrochloric acid was varied from 1.5 to $3.0 \mathrm{~mol} \mathrm{~L}^{-1}$ and that of sodium acetate from 0.5 to

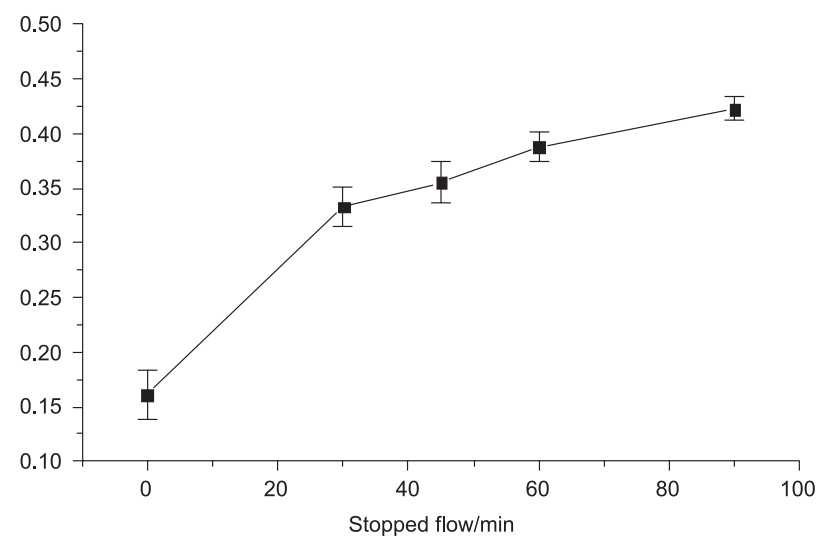

Figure 3. Effect of the reaction time on the stopped flow mode on the signals obtained by the reaction between potassium iodide and Se(IV). In these experiments the Se concentration was fixed at $1 \mathrm{mg} \mathrm{L}^{-1}$ being VB concentration $0.05 \%, \mathrm{KI}$ concentration of $2 \%, \mathrm{HCl}$ concentration $2 \mathrm{~mol} \mathrm{~L}^{-1}$ and sodium acetate $1 \mathrm{~mol} \mathrm{~L}^{-1}$. The length of B1 was fixed at $120 \mathrm{~cm} ;(\mathrm{n}=4)$.

$2.0 \mathrm{~mol} \mathrm{~L}^{-1}$. Hydrochloric acid $2.5 \mathrm{~mol} \mathrm{~L}^{-1}$ and sodium acetate $1.0 \mathrm{~mol} \mathrm{~L}^{-1}$ were selected in order to assure a $\mathrm{pH}$ around 1.2 for the first reaction and 4.5 for the second one. For potassium iodide, concentrations below $2 \%(\mathrm{~m} / \mathrm{v})$ limited the analytical sensitivity and concentrations higher than $2 \%$ increase the blank values. The concentration of VB was fixed $0.05 \%(\mathrm{~m} / \mathrm{v})$ for all studies.

\section{Analytical performance}

Table 2 compares the analytical features of the proposed and bibliography procedures. The proposed multicommutation procedure, that use the $100 \mathrm{~mm}$ flow injection cell, provides calibration equations of the same order than batch and FIA. The proposed method provides a limit of detection of the same order than that obtained by using NPDPTC after a previous separation of the gas phase generation, ${ }^{9}$ and clearly lower than other photometric procedures. ${ }^{3,7,8}$ It seems that kinetic spectrophotometric approaches provide an enhancement of the LOD and astonishing the sensitivity reported for FIA spectrophotometric determination with MBTH is one order of magnitude better than that obtained by us. However, on looking through the aforementioned study, ${ }^{12}$ it can be seen that authors reported a sensitivity of 0.1875 for the concentration range between 0.050 and $0.500 \mathrm{mg} \mathrm{L}^{-1}$ which is clearly lower than the value of 0.501 obtained in this study for the range between 0.010 and $0.500 \mathrm{mg} \mathrm{L}^{-1}$ and thus it is surprising that they could found a LOD of $0.00025 \mathrm{mg} \mathrm{L}^{-1}$ nor for using a $2 \sigma$ criterion.

The detection limit $(3 \sigma / \mathrm{S})$ obtained for the proposed method was $0.004 \mathrm{mg} \mathrm{L}^{-1}$ The calibration graph, obtained in the range between 0.010 and $0.500 \mathrm{mg} \mathrm{L}^{-1}$, provided an equation $\Delta \mathrm{A}=0.501( \pm 0.004) \mathrm{C}$ with a correlation 
Table 2. Analytical performance of spectrophotometric methods proposed in bibliography for the determination of selenium in water samples

\begin{tabular}{|c|c|c|c|c|c|c|c|}
\hline & Proposed method & Ref. 3 & Ref. 7 & Ref. 8 & Ref. $9^{\mathrm{a}}$ & Ref. 10 & Ref. 12 \\
\hline Linear range / $\left(\mathrm{mg} \mathrm{L}^{-1}\right)$ & $0.01-0.5$ & $0.04-0.4$ & $0.2-2.0$ & $0.02-3.2$ & $0.01-0.12$ & $0.0005-0.1$ & $0.05-0.5$ \\
\hline $\mathrm{LOD} /\left(\mu \mathrm{g} \mathrm{L}^{-1}\right)$ & 4 & 11 & 30 & 17 & 2 & 0.0003 & $0.25^{\mathrm{b}}$ \\
\hline $\mathrm{RSD} /(\%)$ & $1.58-1.84$ & $0.03-0.07$ & $1.7-2.5$ & 0.8846 & - & $1.95-2.10$ & $0.2-1.8$ \\
\hline Reagents & $\mathrm{c}$ & $\mathrm{d}$ & $\mathrm{c}$ & $\mathrm{e}$ & $\mathrm{f}$ & $\mathrm{g}$ & $\mathrm{h}$ \\
\hline Procedure & multicommutation & batch & batch & batch & batch & kinetic & FIA \\
\hline Wavelength / nm & 530 (LED) & 615 & 546 & 515 & 490 & 515 & 530 \\
\hline Reagents consumption / mL & 2.6 & 5.0 & 4.5 & 3 & 336 & 4.2 & 18 \\
\hline Throughput $/ \mathrm{h}^{-1}$ & 23 & 2.5 & - & - & - & - & 10 \\
\hline
\end{tabular}

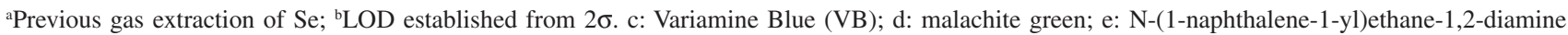
dihydrochloride; f: 2-( $p$-nitrophenyl)-3,5-diphenyltetrazolium choride (NPDPTC); g: Trisodium (4,5-Dihidroxi-3-[( $p$-sulfophenyl)]-2,7-naphihalenedisulfonic acid; h: 3-mentyl-2-benzothiazo linone hydrazone hydrochloride (MBTH).

coefficient of 0.999 . The repeatability was established by the relative standard deviation of 4 measurements at concentrations levels of 0.050 and $0.200 \mathrm{mg} \mathrm{L}^{-1}$ begin found 1.6 and $1.8 \%$ RSD values, respectively. The sampling throughput was of 23 measurements per hour.

\section{Effect of interfering ions}

Natural water is a complex system which can contain several cations and anions, as potential sources of interferences. It was selected thirteen common species usually found in water and results obtained are showed in Table 3. In this study it was fixed a tolerance limit of the interfering species at those concentrations which caused

Table 3. Study of interferences on the determination of selenium by the developed procedure

\begin{tabular}{lcccc}
\hline Interferent & Reagent & $\begin{array}{c}\text { Tolerance limit } \\
\left(\mathrm{mg} \mathrm{L}^{-1}\right)\end{array}$ & $\begin{array}{c}\text { Mass } \\
\text { ratio }\end{array}$ & $\begin{array}{c}\text { Molar } \\
\text { ratio }\end{array}$ \\
\hline $\mathrm{Cl}^{-}$ & $\mathrm{NaCl}$ & 3000 & 10000 & 22295 \\
$\mathrm{CO}_{3}^{2-}$ & $\mathrm{NaHCO}_{3}$ & 3000 & 10000 & 13192 \\
$\mathrm{NO}_{3}^{-}$ & $\mathrm{NaNO}_{3}$ & 2000 & 6666 & 8496 \\
$\mathrm{SO}_{4}^{2-}$ & $\mathrm{Na}_{2} \mathrm{SO}_{4}$ & 2000 & 6666 & 54881 \\
$\mathrm{PO}_{4}^{3-}$ & $\mathrm{Na}_{2} \mathrm{PO}_{4} \mathrm{H}$ & 2000 & 6666 & 5540 \\
$\mathrm{Ca}^{2+}$ & $\mathrm{Ca}\left(\mathrm{NO}_{3}\right)_{2}$ & $2000^{\mathrm{b}}$ & 6666 & 13192 \\
$\mathrm{Zn}^{2+}$ & $\mathrm{Zn}\left(\mathrm{NO}_{3}\right)_{2}$ & $400^{\mathrm{b}}$ & 1333 & 1614 \\
$\mathrm{Al}^{2+}$ & $\mathrm{Al}\left(\mathrm{NO}_{3}\right)_{3}$ & $400^{\mathrm{b}}$ & 1333 & 3746 \\
$\mathrm{Ni}^{2+}$ & $\mathrm{Ni}\left(\mathrm{NO}_{3}\right)_{2}$ & $60^{\mathrm{b}}$ & 200 & 269 \\
$\mathrm{~Pb}^{2+}$ & $\mathrm{Pb}\left(\mathrm{NO}_{3}\right)_{2}$ & $60^{\mathrm{b}}$ & 200 & 76 \\
$\mathrm{Fe}^{2+}$ & $\mathrm{FeNH}\left(\mathrm{SO}_{4}\right)_{2}$ & $10^{\mathrm{b}}$ & 33 & 47 \\
$\mathrm{Fe}^{3+}$ & $\mathrm{Fe}\left(\mathrm{NO}_{3}\right)_{3}$ & $10^{\mathrm{b}}$ & 33 & 47 \\
$\mathrm{Cu}^{2+}$ & $\mathrm{Cu}\left(\mathrm{NO}_{3}\right)_{2}$ & $10^{\mathrm{b}}$ & 33 & 41 \\
\hline
\end{tabular}

Notes: Studies were made for a fixed concentration of $0.3 \mathrm{mg} \mathrm{L}^{-1} \mathrm{Se}(\mathrm{IV})$. ${ }^{a}$ No interference up to signal variation lower than $5 \%$ in presence of the interfering species.

${ }^{\mathrm{b}}$ Measurements made in the presence of $3500 \mathrm{mg} \mathrm{L}^{-1}$ of the EDTA. no more than $5.0 \%$ changes in the absorbance peak height of a $0.300 \mathrm{mg} \mathrm{L}^{-1} \mathrm{Se}$ solution.

Table 3 summarizes the limits of the interfering ions evaluated for the determination of Se, being confirmed the excellent selectivity of the method proposed showing a wide tolerance for the assayed chemical species and no severe interfering effect takes place. Besides, taking into account that the maximum acceptable concentration of those species in waters are lower than tolerance limit found, the procedure could be useful for selenium determination in waters.

\section{Application}

The proposed method was applied for the determination of Se in 9 water, river and bottle mineral samples. All samples presented concentrations of selenium lower that the detection limits of both, the multicommuted proposed method $\left(0.004 \mathrm{mg} \mathrm{L}^{-1}\right)$ and the reference HGAFS procedure $\left(0.009 \mu \mathrm{g} \mathrm{L}^{-1}\right)$. Because of that, samples were spiked at levels between 0.050 and $0.200 \mathrm{mg} \mathrm{L}^{-1}$ and recovery percentage data are summarised in Table 4. As we can see recoveries varied from 98 to $103 \%$. On the other hand the regression between values found by the recommended procedure $(\mathrm{Y})$ and those obtained by HG-AFS (X) for spiked samples provided a regression equation $\mathrm{Y}=0.97( \pm 0.02) \mathrm{X}-0.002( \pm 0.003)$ with a regression coefficient of 0.996 , which clearly shows the good comparability of both approaches and confirming the validity of the multicommuted procedure. Student's paired $t$-test calculated for the values obtained by both procedures was lower than the theoretical $t$ value (2.056) for $95 \%$ probability level and 26 degree freedom. It can be concluded that the accuracy of the developed procedure is comparable to that found by HG-AFS. 
Table 4. Determination of Se(IV) in spiked water samples

\begin{tabular}{|c|c|c|c|c|}
\hline Matrix* & Added / $\left(\mathrm{mg} \mathrm{L}^{-1}\right)$ & Found / $\left(\mathrm{mg} \mathrm{L}^{-1}\right)^{\mathrm{a}}$ & Recovery / \% & Mean Value \\
\hline & 0.05 & $0.052 \pm 0.003$ & $104 \pm 6$ & \\
\hline \multirow[t]{3}{*}{ River water } & 0.10 & $0.103 \pm 0.003$ & $103 \pm 3$ & $103 \pm 2$ \\
\hline & 0.20 & $0.203 \pm 0.002$ & $101 \pm 1$ & \\
\hline & 0.05 & $0.051 \pm 0.04$ & $102 \pm 8$ & \\
\hline \multirow[t]{3}{*}{ River water } & 0.10 & $0.104 \pm 0.003$ & $104 \pm 3$ & $102 \pm 2$ \\
\hline & 0.20 & $0.203 \pm 0.04$ & $101 \pm 2$ & \\
\hline & 0.05 & $0.049 \pm 0.002$ & $98 \pm 4$ & \\
\hline \multirow[t]{3}{*}{ Mineral water } & 0.10 & $0.105 \pm 0.005$ & $105 \pm 5$ & $102 \pm 4$ \\
\hline & 0.20 & $0.200 \pm 0.003$ & $104 \pm 1$ & \\
\hline & 0.05 & $0.052 \pm 0.001$ & $104 \pm 2$ & \\
\hline \multirow[t]{3}{*}{ Mineral water } & 0.10 & $0.104 \pm 0.001$ & $104 \pm 1$ & $101 \pm 5$ \\
\hline & 0.20 & $0.193 \pm 0.002$ & $96 \pm 1$ & \\
\hline & 0.05 & $0.049 \pm 0.001$ & $98 \pm 2$ & \\
\hline \multirow[t]{3}{*}{ Mineral water } & 0.10 & $0.097 \pm 0.002$ & $97 \pm 2$ & $98 \pm 1$ \\
\hline & 0.20 & $0.196 \pm 0.003$ & $98 \pm 1$ & \\
\hline & 0.05 & $0.049 \pm 0.001$ & $98 \pm 2$ & \\
\hline \multirow[t]{3}{*}{ Mineral water } & 0.10 & $0.102 \pm 0.003$ & $102 \pm 3$ & $101 \pm 2$ \\
\hline & 0.20 & $0.205 \pm 0.004$ & $102 \pm 2$ & \\
\hline & 0.05 & $0.048 \pm 0.002$ & $97 \pm 4$ & \\
\hline \multirow[t]{3}{*}{ Mineral water } & 0.10 & $0.100 \pm 0.001$ & $100 \pm 1$ & $100 \pm 3$ \\
\hline & 0.20 & $0.207 \pm 0.002$ & $103 \pm 1$ & \\
\hline & 0.05 & $0.049 \pm 0.001$ & $98 \pm 2$ & \\
\hline \multirow[t]{3}{*}{ Mineral water } & 0.10 & $0.103 \pm 0.002$ & $102 \pm 2$ & $101 \pm 2$ \\
\hline & 0.20 & $0.205 \pm 0.004$ & $102 \pm 2$ & \\
\hline & 0.05 & $0.048 \pm 0.001$ & $96 \pm 2$ & \\
\hline \multirow[t]{2}{*}{ Mineral water } & 0.10 & $0.102 \pm 0.003$ & $102 \pm 3$ & $99 \pm 3$ \\
\hline & 0.20 & $0.201 \pm 0.004$ & $100 \pm 2$ & \\
\hline
\end{tabular}

*Actual concentrations of Se(IV) in all samples were lower than detection limits obtain by LED photometry $\left(4 \mu \mathrm{L}^{-1}\right)$.

${ }^{\mathrm{a}}$ Mean \pm standard deviation $(\mathrm{n}=3)$.

\section{Conclusions}

The use of micro-pumping multicommutation approach together a home-made LED-photometer with a long path cell enhances the sensitivity of the batch photometric determination of Se seven times and reduces the reagents consume also improving the sampling throughput. The proposed procedure offers a sustainable alternative to the previously proposed methods for selenium determination in water (see Table 2), reducing reagents consumption and waste generation. In front of batch procedures, multicommutation facilitates handling of solutions, minimizes risks for the analyst and provides a more environmental sustainable procedure.

\section{Acknowledgments}

The authors acknowledge financial support from CAPES/MECD (Brazil; proc. 042/03 CNPq), Ministerio de Educación, Cultura y Deporte (Spain; ref. PHB2002-0054-
PC), Ministerio de Educación y Ciencia (Spain; project CTQ2005-05604/BQU), Direcció General d'Investigació i Transferència Tecnològica de la Generalitat Valenciana (project ACOMP06-161), Acción Especial de la Universitat de Valencia (project UV-AE-20070213) and CAPES/ MECD (proc. BEX1655/06-0).

\section{References}

1. Sanz, M. A.; Diaz. C. R.; Chem. Rev. 1995, 95, 227.

2. Parkman, H.; Hultberg, H; IVL-Rapport (Swedish), 2002, B1486, 1.

3. Revanasiddappa, H. D.; Dayananda, B. P.; Cent. Eur. J. Chem. 2006, 4, 592.

4. APHA; Standard Methods for the Examination of Water and Wastewater, $19^{\text {th }}$ ed., American Public Health Association: Washington, DC, 1995.

5. Isaeev, L. K.; Control of Chemical and Biological Environmental Parameters, Krismas: St. Petersburg, 1998. 
6. Spallholz, J. E.; Martin, J. L.; Ganther, H. E.; Selenium in Biology and Medicine, AVI Publishing Co Inc.: Westpor, CT, 1981.

7. Revanasiddappa, H.D.; Kumar, T. N. K.; Anal. Sci. 2001, 17, 1309.

8. Suvardhan, K. L.; Krishnaiah, K. S.; Kumar, D.; Rekha, B.; Jayraj, S.; Ramanaiah, P. C.; Chemosphere 2006, 62, 899.

9. Moskvin, L. N.; Bulatov, A.V.; Rudenko, E. A.; Navolotskii, D.V.; Koldobskii, G. I.; J. Anal. Chem. 2006, 61, 25.

10. Keyvanfard, M.; Sharifian, A.; J. Anal. Chem. 2006, 61, 596.

11. Afkhami, A.; Madrakian, T.; Talanta 2006, 58, 311.

12. Rekha, D.; Suvardhan, K.; Kumar, K. S.; Naidu, G. R. K. P.; Chiranjeevi; J. Anal. Chem. 2006, 61, 1177.

13. Araujo, A. N.; Conta, R. C. C.; Lima, J. L. F. C.; Reis, B. F.; Anal. Chim. Acta 1998, 358, 111.

14. Reis, B. F.; Giné, M. F.; Zagatto, E. A.G.; Lima, J. L. F. C.; Lapa, R. A. S.; Anal. Chim. Acta 1994, 293, 129.

15. Lapa, R. A. S.; Lima, J. L. F. C.; Reis, B. F.; Santos, J. L.M.; Zagatto, E. A. G.; Anal. Chim. Acta 2002, 466, 125.
16. Lavorante, A. F.; Morales-Rubio, A.; de la Guardia, M.; Reis, B. F.; Anal. Bioanal. Chem. 2005, 381, 1305.

17. Lavorante, A. F.; Pires, C. K.; Reis, B. F.; J. Pharm. Biomed. Anal. 2006, 42, 423.

18. de la Guardia, M.; Ruzicka, J.; Analyst 1995, 120, 170.

19. de la Guardia, M.; J. Braz. Chem. Soc. 1999, 10, 429.

20. Clesceri, L. S.; Greenberg, A. E.; Eaton, A. D.; Standard Methods for the Examination of Water and Wastewater, $20^{\text {th }}$ ed., American Public Health Association: Washington DC, 1998, p. 108.

21. Rodenas-Torralba, E.; Rocha, F. R. P.; Reis, B. F.; MoralesRubio, A.; de la Guardia, M.; J. Autom. Methods Manag. Chem. 2006, 1.

22. Pires, C. K.; Reis, B. F.; Morales-Rubio, A.; de la Guardia, M.; Talanta 2007, 72, 1370.

Received: October 12, 2008

Web Release Date: May 15, 2009

FAPESP helped in meeting the publication costs of this article. 